\title{
Spontaneous coronary artery dissection
}

\author{
K N Asrress, ${ }^{12}$ A P Banning, ${ }^{2}$ A R J Mitchell ${ }^{1}$ \\ ${ }^{1}$ Department of Cardiology, Jersey Heart \& Lung Unit, Jersey, Channel Islands \\ ${ }^{2}$ Oxford Heart Centre, John Radcliffe Hospital, Oxford, UK
}

Correspondence to K N Asrress, kna@doctors.org.uk

\section{Summary}

We present a case of a 43-year-old lady who presented with an acute coronary syndrome, but without any cardiac risk factors or previous cardiac symptoms, and who had a spontaneous coronary artery dissection. This was successfully treated with percutaneous coronary intervention. A brief discussion of this clinical entity and literature review is presented.

\section{BACKGROUND}

This case highlights an uncommon disorder, often fatal, which can present in young, and otherwise healthy, individuals and which is important to distinguish from the other, much more common causes of chest pain.

\section{CASE PRESENTATION}

A 42-year-old lady presented with a 12 -h history of central chest pain. This began with a slight aching in the arms followed immediately by sudden onset of severe central chest pain, associated with shortness of breath, nausea and sweating. The pain was not pleuritic in nature and was not affected by posture.

Past medical history was unremarkable. Particularly, there was no history of cardiovascular disease or thromboembolism. The patient had no history of hypertension, diabetes mellitus, family history of cardiovascular disease or history of cigarette smoking. There was no history of connective tissue disorders.

Physical examination was entirely normal, including blood pressure in both arms, heart rate, cardiovascular, respiratory, musculoskeletal and abdominal systems.

\section{INVESTIGATIONS}

Initial blood tests, including a full blood count, urea, creatinine, electrolytes, C-reactive protein, liver function tests, amylase and lipid profile, were normal. Admission troponin I was raised at $5.1 \mu \mathrm{g} / \mathrm{l}$ (normal range $<0.2$ ). A chest $\mathrm{x}$-ray was reported as normal.

Electrocardiography on admission revealed normal sinus rhythm and inverted T-waves in leads III and aVF. Two hours later, in the absence of symptoms, there was flattening of T-waves in leads V5, 6 and II. Transthoracic echocardiography showed a structurally and functionally normal heart with no significant regional-wall-motion abnormality.

\section{DIFFERENTIAL DIAGNOSIS}

The main differential diagnoses were ischaemic cardiac pain, acute pericarditis, myocarditis or pulmonary embolism. Other, less common differentials to consider in a woman with minimal risk factors for coronary artery disease are spontaneous coronary artery dissection and paradoxical coronary embolism, usually through a patent foramen ovale.

\section{TREATMENT}

Treatment was commenced for presumed acute coronary syndrome with aspirin, clopidogrel, enoxaparin, simvastatin and bisoprolol. The patient then underwent cardiac catheterisation. Coronary angiography and intravascular ultrasound revealed spontaneous coronary dissection of the left intermediate coronary artery (figure 1, video 1 ). This was successfully treated with percutaneous coronary intervention and coronary stenting to the affected segment of artery, with an excellent angiographic result (figure 2, video 2). Recovery was unremarkable.

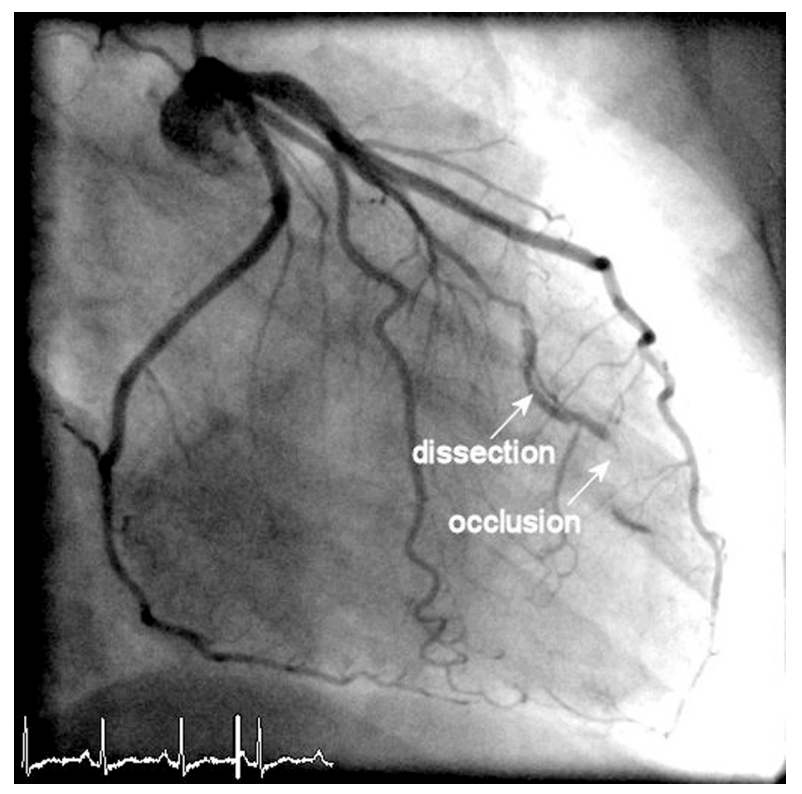

Figure 1 Coronary angiogram showing dissection of the intermediate artery with distal occlusion of the vessel.

Video 1 Left coronary angiogram showing dissection of the intermediate artery. 10.1136/bcr.06.2008.0221v1 


\section{BMJ Case Reports}

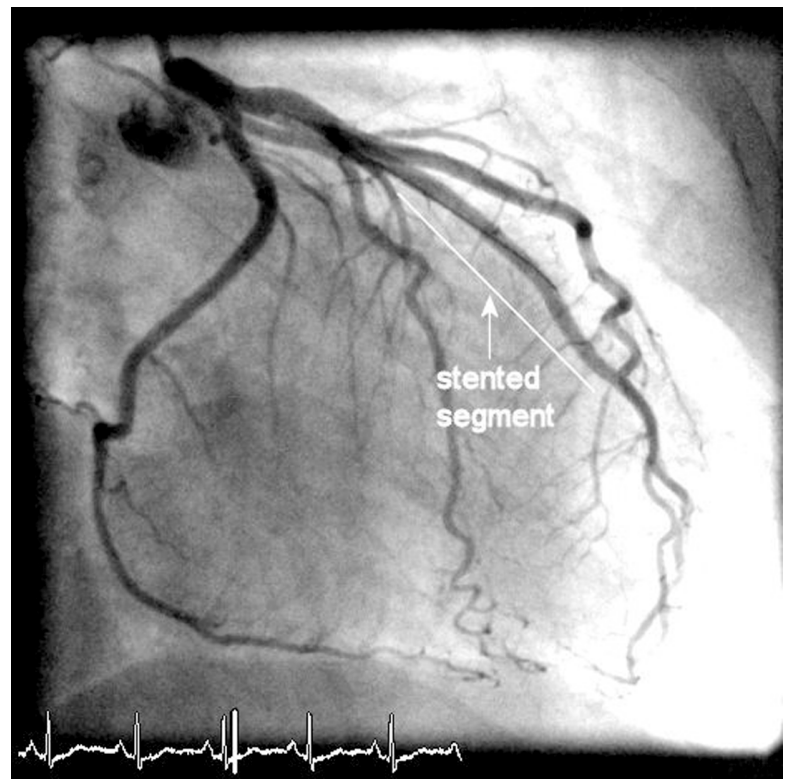

Figure 2 Coronary angiogram following stenting of the dissected artery segment (guide wire in situ).

Video 2 Left coronary angiogram following deployment of a coronary stent that has restored flow to the dissected intermediate artery (angioplasty wire in situ). 10.1136/bcr.06.2008.0221v2

\section{OUTCOME AND FOLLOW-UP}

The patient made a good recovery and was successfully discharged from hospital, with a plan for treatment with clopidogrel for 1 year and aspirin lifelong.

\section{DISCUSSION}

This case highlights a condition that is a rare cause of acute myocardial infarction, whose aetiology is poorly understood, and optimal management has not been clearly elucidated. Over 100 cases of spontaneous coronary dissection have been reported in the English literature since the first case was described in $1931 .{ }^{1}$ It is more common among women and young patients, with women accounting for approximately $73 \%$ of cases with a mean age at presentation of 39 years. ${ }^{2}$ Presentation can involve the full spectrum of acute coronary syndrome manifestations, but sudden cardiac death is the most common. ${ }^{1}$

Spontaneous coronary artery dissection is characterised by a plane that usually runs in the outer media or between the media and adventitia of the coronary artery, resulting in haemodynamic compromise due to the flap, with blood tracking in it, compressing the lumen. ${ }^{3}$ The aetiology of this disease is poorly understood. Most affected patients do not have risk factors for coronary heart disease. The risk of spontaneous coronary artery dissection is increased during the peri-partum period with $25-31 \%$ of reported cases occurring during this time. ${ }^{12}$ Other predisposing factors include the Marfan and Ehlers-Danlos syndromes and atherosclerosis. Potential triggers of the actual dissecting event include physical exercise, prolonged straining and sneezing. ${ }^{4}$ These all result in momentary elevation in coronary artery pressure.

As it is infrequent, the evidence for the optimal management of spontaneous coronary artery dissection is limited. The management strategy depends on the clinical situation and the size of the affected artery segment. All suspected cases should undergo urgent coronary angiography. Accepted treatments include percutaneous coronary intervention, coronary artery bypass grafting or conservative medical management. There are no data to support the routine use of antiplatelets, although their use in this case was to prevent occlusion or thrombosis of the implanted coronary stent. Thrombolysis is no longer knowingly used because of its potential to worsen the dissection process.

Spontaneous coronary dissection should always be considered in any young patient, especially women, without classical cardiac risk factors that present with an acute coronary syndrome or cardiac arrest.

\section{Learning points}

Consider spontaneous coronary dissection in:

- Patients presenting with sudden onset ischaemic sounding chest pain.

- Young female patients with no cardiac risk factors and evidence of cardiac ischaemia.

- Pregnant/postpartum patients.

Competing interests None.

Patient consent Obtained.

\section{REFERENCES}

1. Basso C, Morgagni GL, Thiene G. Spontaneous coronary artery dissection: a neglected cause of acute myocardial ischaemia and sudden death. Heart 1996;75:451-4.

2. DeMaio SJ Jr, Kinsella SH, Silverman ME. Clinical course and long-term prognosis of spontaneous coronary artery dissection. Am J Cardiol 1989;64:471-4.

3. Parry R, MacConnell T, Wilde P. Case report: spontaneous coronary artery dissection. Clin Radiol 1994;49:142-3.

4. Butler R, Webster MW, Davies G, et al. Spontaneous dissection of native coronary arteries. Heart 2005;91:223-4. 


\section{BMJ Case Reports}

This pdf has been created automatically from the final edited text and images.

Copyright 2010 BMJ Publishing Group. All rights reserved. For permission to reuse any of this content visit http://group.bmj.com/group/rights-licensing/permissions.

BMJ Case Report Fellows may re-use this article for personal use and teaching without any further permission.

Please cite this article as follows (you will need to access the article online to obtain the date of publication).

Asrress KN, Banning AP, Mitchell ARJ. Spontaneous coronary artery dissection. BMJ Case Reports 2010;10.1136/bcr.06.2008.0221, date of publication

Become a Fellow of BMJ Case Reports today and you can:

- Submit as many cases as you like

Enjoy fast sympathetic peer review and rapid publication of accepted articles

Access all the published articles

- Re-use any of the published material for personal use and teaching without further permission

For information on Institutional Fellowships contact consortiasales@bmjgroup.com

Visit casereports.bmj.com for more articles like this and to become a Fellow 